\title{
Karakteristik Ukuran Tubuh Kambing Peranakan Ettawa Pada Periode Dara dan Laktasi 1 Di Kelompok P4S Agribisnis Assalam Indihiang Kabupaten Tasikmalaya (Body Size Characteristics of Ettawa Breed Goat in Doe Kid and First Lactation Period in the P4S Agribusiness Group Assalam Indihiang Tasikmalaya Regency)
}

\author{
Raden Febrianto Christi ${ }^{1}$, Lia Budimulyati Salman ${ }^{2}$, Hermawan $^{3}$, Dwi Suharwanto ${ }^{4}$ \\ ${ }^{1,2,3,4}$ Laboratorium Produksi Ternak Perah Fakultas Peternakan Universitas Padjadjaran Sumedang \\ Email : raden.febrianto@unpad.ac.id
}

\begin{abstract}
Abstrak
Kambing perah peranakan ettawa merupakan jenis tipe ternak dwiguna dimana menghasilkan produk utama susu kemudian daging. Sifat karakteristik kuantitatif pada ternak perah menentukan produktivitas dari suatu ternak. Penelitian dilaksanakan di Kelompok P4S Agribisnis Assalam Kecamatan Indihiang, Kabupaten Tasikmalaya pada bulan November 2019. Tujuan penelitian adalah mengetahui karakteristik kuantitaif pada kambing perah peranakan ettawa berbagai umur yang meliputi panjang badan, lingkar dada, dan tinggi badan. Metode penelitian yang digunakan adalah analisis deskriptif kuantitatif. Sampel yang digunakan sebanyak 15 ekor betina kambing yang terdiri atas periode dara 7 ekor, laktasi 1 sebanyak 8 ekor. Hasil menunjukkan bahwa pada periode dara didapatkan rata-rata panjang badan $64,14 \mathrm{~cm}$ koefisien variasi $0,14 \%$, lingkar dada 73,21 cm koefisien variasi $0,12 \%$, dan tinggi badan $54,42 \mathrm{~cm}$ koefisien variasi $0,008 \%$, pada laktasi 1 rata-rata panjang badan $71,75 \mathrm{~cm}$ koefisien variasi $0,077 \%$, lingkar dada $84,06 \mathrm{~cm}$ koefisien variasi $0,085 \%$, tinggi badan $55,53 \mathrm{~cm}$ koefisien variasi $0,010 \%$. Kesimpulan menyatakan bahwa karakteristik ukuran tubuh kambing perah pada periode dara dan laktasi 1 sesuai dengan Standar Nasional Indonesia (SNI) yang ada.
\end{abstract}

Kata kunci: ukuran tubuh, kambing peranakan ettawa, dara, laktasi 1, tasikmalaya

\section{Abstrack}

The ettawa crossbreed dairy goats are a type of dual-use livestock which produces the main products of milk and then meat. Quantitative characteristics in dairy cattle determine the productivity of an animal. The research was carried out in the Assalam Agribusiness P4S Group, Indihiang Subdistrict, Tasikmalaya District in November 2019. The aim of the study was to determine the quantitative characteristics of the various dairy goats of different breeds including age, body length, chest circumference, and height. The research method used is quantitative descriptive analysis. The samples used were 15 goat females consisting of a doe kid period of 7 tails, lactation 1 of 8 tails. The results showed that in the doe kid period an average body length of $64.14 \mathrm{~cm}$ coefficient of variation $0.14 \%$, chest circumference $73.21 \mathrm{~cm}$ coefficient of variation $0.12 \%$, and height $54.42 \mathrm{~cm}$ coefficient of variation $0.008 \%$, at lactation 1 average body length $71.75 \mathrm{~cm}$ coefficient of variation $0.077 \%$, chest circumference $84.06 \mathrm{~cm}$ coefficient of variation $0.085 \%$, body height $55.53 \mathrm{~cm}$ coefficient of variation $0.010 \%$. The conclusion states that the body size characteristics of dairy goats in the doe kid and lactation period 1 are in accordance with the existing Indonesian National Standards (SNI).

Keywords: body size, ettawa crossbreed goat, doe kid, lactation 1, tasikmalaya

\section{Pendahuluan}

Kambing Peranakan Etawa (PE) merupakan salah satu jenis ternak ruminansia kecil dengan hasil persilangan antara kambing Etawa asli India dan kambing Kacang asli Indonesia. Secara manfaat ternak ini diklasifikasikan sebagai ternak dwiguna yang mampu menghasilkan produk utama berupa susu dan daging untuk dimanfaatkan oleh manusia. 
Kambing PE dapat menghasilkan susu berkisar 0,5-1 liter/hari/ekor dengan harga Rp. 25.000,00/liter (Sasongko dkk., 2004). Keistimewaan susu kambing ini dibandingkan dengan susu sapi sangat banyak khasiatnya diantaranya menyembuhkan berbagai macam penyakit asma, hepatitis, TBC, anemia, masalah otot, dan lambung. Disamping itu, susu kambing juga memiliki kandungan nutrient atau gizi lengkap yang dibutuhkan oleh manusia untuk tumbuh kembang seperti lemak, laktosa, protein, dan mineral (Christi dan Rochana, 2018). Karakteristik seekor ternak dapat dilihat dari tampak dalam (Internal) dan luar (Eksternal) yang dinyatakan dengan ekspresi genetik dan lingkungan. Sumbangan genetik memberikan kontribusinya sebesar 30\% dan lingkungan yang meliputi manajemen dalam proses pemeliharaanya yaitu $70 \%$.

Sifat Kuantitatif dan kualitatif dari seekor ternak umumnya jarang terpisahkan karena memiliki keterkaitan yang sangat penting. Ciri-ciri kambing peranakan etawa antara lain dibagi ke dalam 3 bagian yaitu kepala, badan, dan kaki. Dimana tubuh yang dimiliki kambing cukup besar biasanya bagian tubuh corak hitam putih, tinggi badan 75-100 $\mathrm{cm}$ daun telinga panjang 18-19 cm, muka cembung, bulu pada paha belakang panjang, dan berat badan jantan $40 \mathrm{~kg}$ dan betina $35 \mathrm{~kg}$. Ambing pada kambing PE sangat besar bila dibandingkan dengan jenis kambing perah lainnya seperti saanen, sapeera, jawarandu (Saifuddin, 2003). Performan kambing yang biasa dijadikan penilaian performan adalah panjang badan lingkar dada dan tinggi badan.

Kambing perah PE betina pada berbagai periode yaitu mulai dara sampai dengan laktasi dalam proses pewarisan genetik sangatlah penting maka penelitian mengenai karakteristik sifat kuantitatif kambing PE betina perlu dilakukan. Ukuran-ukuran tubuh seperti panjang badan, lingkar dada, dan tinggi badan dapat dijadikan sebagai acuan dalam menentukkan produktivitas dari suatu ternak khususnya pada Kelompok P4S Agribisnis Assalam Indihiang Kabupaten Tasikmalaya.

\section{Metodologi Penelitian}

\section{Tempat Penelitian}

Penelitian ini dilaksanakan pada november 2019 yang bertempat di Kelompok Peternakan Kambing Perah P4S Agribisnis Assallam Kabupaten Tasikmalaya.

\section{Materi Penelitian}


Jurnal Sains Peternakan

Volume 7 No. 2, Desember 2019, pp:122-127

ISSN 2579-445

Materi yang dijadikan penelitian adalah 15 ekor kambing betina peranakan etawa dengan berbagai periode yaitu dara 7 ekor, laktasi 1 sebanyak 8 ekor,. Ukuran tubuh kambing PE diperoleh langsung dengan cara mengukur peubah ukuran tubuh yang diamati yaitu panjang badan, lingkar dada dan tinggi badan. Metode pengambilan sampel yang dijadikan objek penelitian menggunakan purposive sampling.

\section{Analisis Statistik}

Analisis statistik yang digunakan adalah analisis deskriptif. Data dideskripsikan terhadap nilai rata-rata, simpangan baku atau standar deviasi, dan koefisien variasi.

\section{Hasil dan Pembahasan}

\section{Karakteristik Panjang Badan, lingkar Dada, dan Tinggi Badan Periode Dara dan}

\section{Laktasi 1 Kambing Peranakan Etawa}

Pengukuran kuantitif pada suatu ternak sangat penting dilakukan hal ini digunakan untuk menduga produktivitasnya. Umumnya karakteristik sifat kuantitatif meliputi panjang badan, lingkar dada, dan tinggi badan. Setiap periode perkembangan dari seekor ternak tentu akan menghasilkan nilai ukur yang berbeda. Nilai karakteristik tersebut disajikan pada Tabel 1 berikut ini.

Tabel 1. Karakteristik Panjang Badan, Lingkar Dada, dan Tinggi Badan Dara Kambing Peranakan Etawa

\begin{tabular}{llclc}
\hline No & \multicolumn{1}{c}{ Nilai } & Panjang Badan & Lingkar Dada & Tinggi Badan \\
\hline 1 & Rata-rata sampel & $64,14 \mathrm{~cm}$ & $73,21 \mathrm{~cm}$ & $54,07 \mathrm{~cm}$ \\
2 & Simpangan baku & 9,51 & 9,22 & 0,64 \\
3 & Koefisien Variasi & $0,14 \%$ & $0,12 \%$ & $0,011 \%$ \\
\hline
\end{tabular}

Tabel 2. Karakteristik Panjang Badan, Lingkar Dada, dan Tinggi Badan Periode Laktasi 1 Kambing Peranakan Etawa

\begin{tabular}{llrrr}
\hline No & Nilai & Panjang Badan & Lingkar Dada & Tinggi Badan \\
\hline 1 & Rata-rata sampel & $71,75 \mathrm{~cm}$ & $84,06 \mathrm{~cm}$ & $55,53 \mathrm{~cm}$ \\
2 & Simpangan baku & 5,57 & 7,17 & 0,53 \\
3 & Koefisien Variasi & $0,077 \%$ & $0,085 \%$ & $0,009 \%$ \\
\hline
\end{tabular}

Tabel 1 menunjukkan bahwa rata-rata panjang badan, lingkar dada dan tinggi badan pada kambing PE dara di Kelompok ternak P4S Agribisnis Assalam adalah 64,14 cm, 73,21 $\mathrm{cm}$, dan tinggi badan 54,07 $\mathrm{cm}$. Sedangkan pada Tabel 2 kambing laktasi 1 menghasilkan 
ukuran panjang badan $71,75 \mathrm{~cm}$, lingkar dada $84,06 \mathrm{~cm}$ dan 55,53 $\mathrm{cm}$. Hal tersebut apabila dibandingkan dengan Standar Nasional Indonesia (2008) pada periode dara dan laktasi ke-1 sangat memenuhi persyaratan karena melebihi nilai dari ketentuannya yaitu 58-60 cm. Simpangan baku pada masing-masing parameter pada periode tertentu yang diamati memiliki pengertian bahwa nilai yang didapatkan digunakan untuk menghasilkan koefisien variasi. Koefisien variasi yang didapatkan menunjukkan bahwa pada semua parameter yang diamati pada Tabel 1 dan Tabel 2 masih dibawah 5\% artinya panjang badan, lingkar dada, dan tinggi badan relatif seragam. Panjang badan pada kambing perah peranakan etawa periode dara dan laktasi ke 1 dipengaruhi oleh proses pertumbuhan yang dimulai sejak cempe lahir sampai dengan periode dara bahkan sampai mencapai titik tertinggi yaitu periode laktasi. Hal ini pendapat Sampurna dan Suatha (2010) bahwa pertumbuhan adalah proses perubahan bentuk seekor ternak sejak lahir sampai fase tertentu dengan bertambahnya massa tubuh seperti panjang badan. Pendapat lain diungkap oleh Mardhianna dkk., (2015) bahwa pola panjang badan dari suatu ternak yang diamati saling berkaitan dengan kerangka tubuh. Sumbangan faktor genetik dan lingkungan dari hidupnya sangat mempengaruhi tumbuh kembang dari seekor ternak. Aspek genetik memberikan sumbangan 30\% terhadap tubuh cempe kambing perah dari tetuanya sedangkan lingkungan memberikan pengaruh sebesar 70\%. Aspek lingkungan salah satunya adalah manajemen pemberian pakan, dimana pemberian hijauan, leguminosa serta konsentrat sangat berperan penting terhadap tumbuh kembangnya seekor ternak kambing (Rismaniah, 2001). Hal ini karena, di dalam pakan tersebut terdapat banyak komponen-kompenen zat makanan yang dibutuhkan untuk hidup pokok seperti protein, lemak, serat kasar, mineral, vitamin yang dikonversikan menjadi sebuah energi (Astuti, 2008). Ukuran tubuh lainnya seperti lingkar dada dan tinggi badan umumnya sama seperti panjang badan.

Lingkar dada dipengaruhi oleh manajamen pemberian pakan serta manajemen perkandangan. Menurut Kahar (2014) bahwa lingkar dada dari seekor ternak sangat dipengaruhi oleh ukuran kandang. Oleh karena itu, penting sekali untuk menentukan ukuran tiap meter pada seekor ternak agar posisi dalam keadaan tegak dan luas, Nilai lingkar dada pada penelitian kambing perah peranakan etawa periode dara sampai laktasi sudah sesuai dengan standarnya, hal ini apabila nilai kurang atau dibawah standar biasanya akan berpengaruh terhadap cara berdiri tegak. Karakteristik luar dari seekor ternak menjadi indikator dalam menentukan produktivitas seekor ternak (Garanjang, 2004). Kemudian tinggi badan dari seekor ternak semakin umur bertambah maka semakin bertambah pula tinggi 
Jurnal Sains Peternakan

Volume 7 No. 2, Desember 2019, pp:122-127

ISSN 2579-445

badannya kecuali diluar faktor genetik. Hal ini faktor utama yang mempengaruhi tinggi atau pendeknya badan dari suatu ternak adalah jenis pakan yang diberikan kepada seekor ternak (Khan dkk., 2006).

\section{Kesimpulan}

Kesimpulan menyatakan bahwa karakteristik ukuran tubuh kambing perah pada periode dara dan laktasi 1 sudah sesuai dengan Standar Nasional Indonesia (SNI) yang ada yaitu pada periode dara didapatkan panjang badan $64,14 \mathrm{~cm}$ lingkar dada $73,21 \mathrm{~cm}$ dan tinggi badan $54,42 \mathrm{~cm}$, pada laktasi 1 panjang badan $71,75 \mathrm{~cm}$, lingkar dada $84,06 \mathrm{~cm}$, tinggi badan 55,53 $\mathrm{cm}$.

\section{Daftar Pustaka}

Astuti, M. 2008. Parameter produksi kambing dan domba di daerah dataran tinggi, Kecamatan Tretep, Kabupaten Temanggung. Dalam : Domba dan Kambing di Indonesia. Pros Pertemuan Ilmiah Penelitian Ruminansia Kecil, Bogor, 22-23 November 2008. Puslitbang Peternakan, Bogor.

Christi, R.F. dan A. Rochana. 2018. Karakteristik Fisik Dan Kimia Susu Kambing Perah Peranakan Ettawa Yang Diberi Konsentrat Fermentasi. Journal of Animal Husbandry Science Vol 3 No 1 Hal 37-42 Program Studi Peternakan Fakultas Peternakan Universitas Garut.

Garantjang, S. 2004. Pertumbuhan anak kambing Kacang pada berbagai umur induk yang dipelihara secara trasidional. J. Sains dan Teknologi. 4(1):40-45.

Kahar, W.L. 2014. Perbandingan Dimensi Tubuh Kambing Kacang Yang Dipelihara Secara Intensif dan Semi Intensif. Jurusan Produksi Ternak Fakultas Peternakan Universitas Hassanudin, Makkasar.

Khan, M., F. Muhammad, R. Ahmad, G. Nawaz, Rahimullah andM. Zubair. 2006. Relationship ofbody weight with liniear body measurement in Goats. Journal of Agricultural and Biological Science. 1(3): 51-54.

Mardhianna, S.Dartosukarno dan I., W. S. Dilaga. 2015. Hubungan Antara Ukuran-Ukuran Tubuh Dengan Bobot Badan Kambing Jawarandu Jantan Berbagai Kelompok Umur Di Kabupaten Blora. Animal Agriculture Journal 4 (2): 264-267. Fakultas Peternakan dan Pertanian Universitas Diponegoro, Semarang.

Rismaniah, I. 2001. Sistem Pemeliharaan Ternak Kambing dan Domba. Ciawi, Bogor. Fakultas Pasca Sarjana, Universitas Padjajaran, Bandung. 
Saifuddin, I.A., 2003. Pertumbuhan pra sapih anak kambing pada zona Ketinggian yang berbeda di kabupaten Kulon Progo daerah Istimewa Yogyakarta. Fakultas peternakan Universitas Gadjah Mada. Yogyakarta.

Sampurna, I. P.dan I. K. Suatha. 2010. Pertumbuhan alometri dimensi panjang dan lingkar tubuh Sapi Bali Jantan. Jurnal Veteriner. 11(1): 46-51.

Sasongko W.R., Y.G. Bulu., A. Hipi dan A. Surahman. 2004. Potensi kambing lokal yang dipelihara petani pada agroekosistem lahan kering di Lombok Timur NTB. Prosiding Seminar Nasional. Pusat Penelitian dan Pengembangan Sosial Ekonomi Pertanian. Badan Litbang Pertanian. Depertemen Pertanian.

Standar Nasional Indonesia 7325:2008. 2008. Kualitas Susu Kambing. Badan Standardisasi Nasional. Jakarta. 